Revue d'histoire de l'Amérique française

RAS REVUE D.HISTOIRE DE L'AMÉRIQUE FRANÇAISE

\title{
The Indians and the Brandy Trade During the Ancien Regime
}

\section{George F. G. Stanley}

Volume 6, numéro 4, mars 1953

URI : https://id.erudit.org/iderudit/301549ar

DOI : https://doi.org/10.7202/301549ar

Aller au sommaire du numéro

Éditeur(s)

Institut d'histoire de l'Amérique française

ISSN

0035-2357 (imprimé)

1492-1383 (numérique)

Découvrir la revue

Citer cet article

Stanley, G. F. G. (1953). The Indians and the Brandy Trade During the Ancien Regime. Revue d'histoire de l'Amérique française, 6(4), 489-505.

https://doi.org/10.7202/301549ar d'utilisation que vous pouvez consulter en ligne.

https://apropos.erudit.org/fr/usagers/politique-dutilisation/ 


\section{THE INDIANS AND THE BRANDY TRADE DURING THE ANCIEN REGIME}

One of the most destructive factors of Indian life during the Ancien Regime was alcohol. Like the aborigenes of Australia, the native peoples of New France had no alcoholic beverage in preColumbia times ${ }^{1}$ and when they were introduced to brandy, rum and whiskey, they developed a craving for the intoxicating liquors of the Europeans which bordered upon frenzy. From the outset the Indians possessed a high susceptibility to the effects o" alcohol, and after experiencing its delights, they displayed a complete absence of self-control and restraint in its consumption. During the Ancien Regime the addiction of the Indians to alcohol became so pronounced that it seriously undermined the health of the native population, stepped up the death rate and lowered the birth rate. Alcohol was as great a killer as war, pestilence and famine. It was one of the four horsemen of the Indian apocalypse.

The French first introduced alcoholic beverages to the Indians in Port Royal. Lescarbot wrote that Membertou was given "quelque bouteille de vin, lequel il aime, parce (dit-il) que quand il en a beu il dort bien, et n'a plus de soin, ni d'appréhension" From this time on alcohol was used both as a means of entertaining and gaining the good will of the Indians and as an article of trade for furs. According to the Jesuit Relations the English introduced brandy to the Indians after the fall of Quebec to the Kirkes; but when the French returned to the St. Lawrence in 1633 this practice became

1. The Indian tribes in Central and South America, such as the Aztecs, Mayas, and Incas appear to have had alcoholic drinks, but only among the Aztecs and their immediate neighbours did drunkenness become a problem. None of the tribes north of Mexico had intoxicating liquors of any kind.

2. M. Lescarbot, The History of New France (3 vols, The Champlain Society, Toronto, 1907), II: 576. 
general. By 1634 drunkeness was fairly widespread among the Montagnais ${ }^{3}$. Within eight years it had spread to the tribe of the Upper St. Lawrence and Great Lakes. By 1663 Pierre Boucher's comment "Tous les Sauvages qui sont proches des Européans deviennent yvrognes"4 was just as true of the Indians of Acadia and of the West, as it was of those who frequented the environs of Three Rivers.

There is no lack of evidence of the baneful effects of the liquor trade upon the Indian tribes. The documents of the Ancien Regime are filled with accounts of debauches, drunken disorders and even murders among the Indians. The Jesuits and Recollets viewed the liquor trade as "l'un des obstacles les plus pernicieux que le Démon pouvoit susciter au salut des François, \& à l'établissement de la Foi parmi ces nations infideles \& barbares"5 and their accounts of its evils are corroborated by the reports of the traders and of the Indians themselves ${ }^{6}$. The stirring condemnations of the Jesuit Relations cannot be dismissed as simple missionary propaganda. There is no exaggeration in their bitter words. "Tous les villages de nos sauuages ne sont plus que des Cabarets pour l'yvrognerie et que des sodomes pour ljmpurete" $"$ is unfortunately an accurate summary of the conditions which prevailed at Michilimackinac and elsewhere in New France.

Nor did these evils abate with time: drunkeness, debauchery, disorder, prostitution, dissolution of family ties, poverty and brutality, violence and murder. They drank only to get drunk and when drunk they became wild beasts. Illustrations may be multiplied without end. The story is always the same. It is true of the Micmac,

3. Les Relations des Jesuites (edit. Thwaites), 1633-34, VI: 250.

4. P. Boucher, Histoire véritable et naturelle des mours et productions du pays de la Nouvelle France (Montréal, 1882), 118.

5. Ch. LeClerq, New Relation of Gaspesia (The Champlain Society, Toronto, 1910), 411.

6. In 1648 a temperance meeting was held at Sillery, "the first in all probability on this continent". An Algonquin chief, who had been converted to Christianity told the other Indians present of the governor's measures against the liquor trade and exhorted them to shun alcoholic beverages. See F. Parkman, The Old Regime in Canada (Boston, 1880, 8th edition), 322.

7. RDJ, LXV: 194; Carheil à Callières, 30 aout 1702. 
the Montagnais, the Algonquin, the Huron, the Iroquois, the Ottawa and the Indians who brought their furs to the western posts of New France.

Broadly speaking the effects of alcoholism upon the Indian nations of Canada were three fold; moral degradation, physical decline, death and depopulation. Alcoholism opened the way for disease. Bouts of drunkeness were of ten followed by heavy sleep under conditions of exposure, thus leading to lung trouble and tuberculisis. Abortions and infanticide became frequent. Father Le Jeune, as early as 1634 wrote that the Indians "voyent bien que ces nouuelles boissons de vin et d'eau de vie... depeuplent leurs pays, \& qu'eux mesmes s'en plaignent"s, but he added that they abstain from drinking, taking pride in getting drunk and making others drunk. A half a century later Governor Denonville reported to France that alcoholism had brought about a serious decline in the numbers of the Indians. Twenty years earlier two thousand Indians had lived in the vicinity of the French settlements where now scarcely thirty people could be gathered together. This, Denonville maintained, was a direct result of the over-consumption of brandy ${ }^{9}$. Another contemporary writer attributed practically all the fatal illnesses to which so many Indians had succombed to a decline in physical health and lack of resistance brought on by over-indulgence in alcohol. "On en a trouvé de mort dans les eaux, sur les chemins, au bord des rivières et dans les bois", he wrote, "ayant encore leur baril d'eau de vie auprez d'eulx"'10.

During the first years of the Ancien Regime both church and State recognized how serious was the problem of Indian alcoholism, and both sought to impose restrictive and prohibitory measures upon the liquor trade. Successive governors, including Champlain ${ }^{11}$,

8. Ibid., 1633-34, VI: 250-2.

9. Public Archives of Canada, C 11 A, 10: 123-4, "mémoire d'un des plus grands maux de la colonie", Denonville à Seignelay, 10 aout 1688. Canada".

10. PAC, C 11 A, 12-2: 542-3, "mémoire touchant l'ivrognerie des sauvages en

11. RDJ, 1632-3, V: 230. 
Montmagny ${ }^{12}$, and Maisonneuve ${ }^{13}$ all issued orders prohibiting the sale of intoxicants to the Indians. In 1636 a regulation required Indians found in a state of intoxication to reveal the names of those who had sold them liquor in order that the culprits might be fined ${ }^{14}$. Twenty years later, on March 7, 1657, the King, acting on the advice of the Jesuits, forbade the sale of liquor to the Indians on pain of fine for the first offence and whipping and banishment for the second $^{15}$. Owing to the difficulty of enforcing this law drunken Indians might be arrested and compelled to inform upon the French vendors ${ }^{16}$. But neither ecclesiastical admonition nor civil threat succeeded in curbing the fatal traffic. Indeed the repeated injunctions against it simply reveal the fact of its steady growth.

In the spring of 1659 Francois de Montmorency-Laval came to Canada as the first bishop. A man of strong will and equally strong conviction nothing less than complete prohibition of the liquor trade would satisfy him. The civil authorities, charged with the responsibility of looking after the interests of the Company of the Hundred Associates, were inclined to wink at the brandy trade and its evils while paying lip service to the ideal of temperance. The fur trade, was after all, the chief source of profit, direct and indirect, to all those interested in the economic development of New France, including the governor. But with Laval there could be no temporizing with the Devil, and the Devil in this instance was intemperance among the Indians. Seeing the fortunes of the "nouveau Christianisme en danger de se ruiner, s'il n'obuioit à ces malheurs", Laval "a appliqué tous ses soins à trouuer remède à ce mal, qui auoit paru jusqu'alors incurable"17. With a high hand he entered upon the work of reform. On May 5, 1660, Bishop Laval took the bold step

12. Ibid., 1642-3, XXIV: 142 .

13. E.M. Faillon, Histoire de la colonie française en Canada (3 vols, Villemarie, 1866), III: 31 .

14. RDJ, 1636, IX: 202-4.

15. Répertoire des arrêts, édits, mandements, ordonnances et réglements, 16401760 (edit. E.Z. Massicotte, Montréal, 1919), 1.

16. M. Eastman, Church and State in Early Canada (Edinburgh, 1915), 78-9.

17. RDJ, 1659-61, XLVI: 104. 
of excommunicating all those who sold intoxicants to the Indians ${ }^{18}$.

For a few years the drastic ecclesiastical measures adopted by Bishop Laval to curb the liquor traffic were effective. Father Lalemant wrote hopefully in his Relation of 1660 that the excommunication had had the desired result and that "tous ces desordres... n'ont plus parû depuis l'excommunication; tant elle a esté accompagné des benedictions du Ciel"19. One may, however, be pardonned for assuming that perhaps the rigorous punishments imposed by the State on Laval's insistence had something to do with the temporary improvement. In the Journal of the Jesuits for 1661 we read that

Daniel Vvil pendu ou plustost arquebuzé, et le 11 vn autre nommé la Violette; f8ete le lundy, 10 pour auoir traité aux sauuages de l'eau de vie ${ }^{20}$.

The success attained by Laval and the clerical party was shortlived. New France was passing from the status of a mission to that of a colony and the commercial interests were growing in strength at the expense of the Church. Pressure was brought to bear upon the administration by those who argued that the only way in which New France could successfully compete with the Anglo-American colonies to the south was to provide the Indians with the alcohol which they demanded. The Dutch, English and Americans, sold rum to the Indians without moral compunctions; should the French and Canadians refuse to include brandy as an article of trade, the thirsty Indians would not only take their beaver skins to the Hudson instead of to the St. Lawrence, but they would imbibe heretical doctrine along with the spirits provided them at Fort Orange. The commercial argument may have been spiced with hypocrisy but it was not unreasonable: it was one which the clergy found difficult

18. Mandements des évêques de Quêbec (Edit. Mgr H. Têtu et l'abbé C.-O. Gagnon (Québec, 1887), 1: 14-5.

19. RDJ, 1659-61, XLVI: 104.

20. Le Journal des Jesuites, publié par les abbés Laverdière et Casgrain, (Montréal, 1892), 303. Daniel Vvil (Will ?) had apparently been a source of trouble in the colony. In the Journal des Jésuites (p. 292) we read: "Grande brouillerie entre les puissances: on en pensa venir aux extremités au suiet d'vne sentence portée par Monseigr. l'Euesque contre Daniel Vvil, prisonnier heretique relaps, blasphemateur et profanateur des Sacremens: cuius crimina utrumque forum sibi vindicabat. Longa hist. de qua alibi fuse. 
to answer and one which carried great weight with Jean-Baptiste Colbert, the King's minister in Paris.

If the arguments of the mercantilists were not unreasonable, neither were those of the clergy. The Indians were not Europeans; their attitude towards alcoholic beverages was not the same as that of Europeans. Regulations which might check the excesses of drunken Frenchmen were useless when dealing with Indians. It was the fact that the Indians were incapable of resisting the solicitations of the brandy peddlars and were completely without inhibitions of any kind when intoxicated that gave such force to the argument for prohibition. Colbert might look upon the control of the liquor traffic entirely "as a police matter and not as a religious matter" the bishop the two were essentially one.

The fundamental conflict between morality and economics, between religious scruple and passion for gain, was aggravated in Canada by a clash of personalities. The friction between Laval and Argenson and between Laval aud Avaugour arose from obvious personal considerations; but the question of sols verus souls underlay all of these quarrels. The haste with which Governor Avaugour made use of Father Lalemant's intercession on behalf of a woman convicted of contravening the anti-liquor laws to free the trade from its prohibitory restrictions affords evidence of a lack of enthusiasm upon the part of the civil authorities for prohibition. To the importunate reverend petitioner Avaugour said "Vous êtes les premiers à crier contre la traite \& vous ne voulez pas qu'on punisse les Traitans? Je ne ferai plus le jouet de vos contradictions; puisque ce n'est pas une faute punissable dans cette femme, elle ne le sera plus pour personne",22. Henceforth brandy flowered freely down the throats of red and white men alike.

Laval quickly renewed his threats of wholesale excommunication but without avail. French and Indians drank not only to get drunk but also to spite the clergy. Charlevoix wrote "bientôt on n'écouta plus, ni Eveque, ni Prédicateurs, ni Confesseurs.... ${ }^{23}$ ". They

21. Report of the Canadian Archives, 1885, xcviii: Dudouyt a Laval, 1677 .

22. L-B de la Tour, Mémoire sur la vie de M. de Laval (Cologne, 1761), 80.

23. Le P. de Charlevoix, Histoire et Description Générale de la Nouvelle France (3 vols., Paris, 1744), I: 361 . 
were upheld by the civil power and could defy spiritual penalities with impunity. They could and did go further. They charged the clergy and the bishop with interfering in matters outside their spiritual jurisdiction; they accused them of unjustly troubling the consciences of the people and even of endangering the economy of the country" ${ }^{24}$ "Mon ancre n'est pas assez noire pour les dépeindre de leurs couleurs" wrote the distracted Lalemant, "il faudroit du fiel de dragons pour coucher icy les amertumes que nous en avons ressenty: C'est tout dire que nous perdons en vn mois les sueurs et les trauaux de dix et vingt années ${ }^{25}$."

Laval stood inflexible. He was determined to return to France to lay his case before the King. In Paris he succeeded, not without difficulty, in obtaining the recall of Avaugour, and what was more important, royal approval for the prohibition of the liquor trade with the Indians in the colony. In September 28, 1663, the Superior Council issued a decree expressly forbidding any trade, direct or indirect in involving the sale of intoxicating liquors to the Indians ${ }^{26}$. But the situation had already improved. Heaven had imposed a warning upon the guilty colony by causing the earth to shake, and "le scandaleux trafic des liqueurs spiritueuses avait cessé comme par enchantement ${ }^{27}$."

Despite the evidence of divine wrath and royal displeasure, intoxicants still reached the thirsty Indians through the colonial version of the modern bootlegger. Soldiers frequently engaged in the illicit trade. One of them, the Sieur de La Frédière, a nephew of Colonel de Salières and a major in the Carignan regiment, turned his quarters in Montreal into a liquor store for the Indians. He was discovered only when the Indians complained to the civil authorities not that he had sold them vast quantities of brandy, but that he mixed too much water in it before selling ${ }^{2}{ }^{28}$ ! The increase in the

24. La Tour, op. cit., 81-2.

25. RDJ, 1662-3, XLVIII: 62.

26. Arrêts et règlements du conseil suptrieur de $Q u e b e c$, et ordonnances et jugements des intendants du Canada, (Québec, 1855), 6-7.

27. C. de Rochemonteix, Les Jésuites et la Nouvelle France au XVIIe siècle (3 vols., Paris, 1895), II: 326. See also Parkman, op. cit., 124-8.

28. Faillon, op. cit., III: 389. 
illicit trade with the Indians was symptomatic of the general lowering of the strict moral standards which has been so outstanding a feature of the early history of Montreal. Taverns, at first established for the convenience of travellers, sprang up in great numbers to meet the demands on the part of the troops; drinking became so widespread that the Intendant Bouteroue was obliged to issue an order, on April 2, 1669, forbidding tavern keepers to sell food and drink to people domiciled in Montreal especially during divine services on Sundays and feast days ${ }^{29}$.

\section{- III -}

The arrival of Jean Talon in Canada as Intendant brought the liquor question to the forefront of Canadian politics. Talon, like his sponsor Colbert, was interested primarily in promoting the prosperity of the colony: the moral aspects of commerce were, in his mind, subordinate to its economic advantages. Thus, despite his initial support of prohibition, Talon came to regard the brandy trade as a necessary means of improving the economic conditions of the colony. The country was in a state of transition. It was no longer a mission. The views of the traders must prevail over those of the ecclesiastics in matters of trade. And the liquor traffic was therefore a matter exclusively for the civil magistrates to regulate. Under Talon's influence the Sovereign Council modified its earlier regulations. The harsh penalties for infractions of the law were replaced by fines, corporal punishments and confiscations of the liquor ${ }^{30}$. Finally, in 1668, the Council repealed all prohibitory regulations and opened the brandy trade with the Indians to all the inhabitants of New France. The members of the Council, smelling profits, did so quite willingly, salving their consciences with the naive injunction to the Indians to remain sober under penalty of the pillory and a fine of two beaver skins $^{31}$. This ordinance was modified in June 1669 to the extent of

29. Ibid., III: 404-5.

30. Jugements et délibérations du conseil souverain de la Nouvelle France, (Québec, 1885), 1: 368, 422-3.

31. Ibid., 1: 535. 
forbidding the sale of liquor in Indian villages but permitting the Indians to purchase it in French settlements ${ }^{32}$.

From the day of its promulgation the regulation forbidding the sale of liquor in Indian villages remained a dead letter. Although it could, to some extent, be enforced in Indian villages like. Sillery, it could not be enforced among the temporary camp sites of the migratory tribes. Traders and coureurs de bois were able to peddle alcohol in all parts of New France without any real fear of interruption. Courcelles might attempt to arrest brandy traders trafficking in the vicinity of Montreal, but the men at his disposal were too few in number to reach into the country beyond. The clergy, led by Laval, continued to fire their ecclesiastical broadsides but to no avail. Unless the civil authorities were prepared to put teeth into the law and back up the clergy in their efforts to curtail Indian intemperance, there was little chance of effective regulation of the liquor traffic.

It is possible that some degree of co-operation might have been possible between Church and State had the governor and bishop been inclined to compromise; but co-operation and compromise were foreign to either Bishop Laval or Governor Frontenac. Their quarrels were, however, not only the conflicts of strong personalities; they were also conflicts of principles. To Frontenac, as to Talon, the brandy trade meant increased profits and prosperity for the colony; to Laval and the Jesuits it meant the ruin of the Indian missions and the degradation of the Indian race. Alcohol was an ugly demon whose misbegotten offspring were debauchery, misery and crime. Both bishop and governor appealed to Paris. The fathers of the Sorbonne, after giving Laval's argument solemn consideration, declared that the sale of brardy to the Indians was a mortal $\sin ^{33}$. But neither the King nor his minister were at heart prohibitionists. Colbert in particular wished to divorce religion from commerce and to separate the moral and economic aspects of the liquor trade. $\mathrm{He}$ therefore suggested that the question might be referred to "vingt principaux habitans du pais au nombre de ceux qui s'appliquent au

32. Ibid., 1: 558-9.

33. "Délibération de la Sorbonne sur la traite de l'eau de vie, 1 février 1662, 8 mars, 1675". See note D in Abbé Gosselin, Vie de Mgr. de Laval, premier évêque de Québec et apôtre du Canada 1662-1708 (2 vols., Québec, 1890), II: 679-683. 
commerce" who should forward their recommendations to the King for his guidance ${ }^{34}$. This meeting, usually known as "The Brandy Parliament", was held on October 26, 1678, at the Chateau of St. Louis, under the watchful eye of Frontenac. Each member sta ed his views in writing. The great majority were for unrestricted trade in brandy: fifteen of these present maintained that it was essential for the economic welfare of the colony. They minimized the evil effects of the liquor trade and opposed all prohibitory regulations ${ }^{35}$. It was, after all, to their interests to take this view; and they were far from the Indian encampments in which the worst orgies were taking place.

It was also to the King's interest to permit the liquor trade. It added gold coins to the royal treasury and helped to maintain the Indian alliances. It is also possible that Louis XIV, like Colbert, resented the attitude of the bishop and the Jesuits as an encroachment on the part of the Church upon the civil jurisdiction: like Colbert, he may also have accepted Frontenac's assertions that the evils of the trade were grossly exaggerated. In any event he favoured the regulation but not the prohibition of the brandy trade with the Indians. On May 24, 1679 a royal ordinance was issued governing the liquor trade in New France ${ }^{36}$. This ordinance consolidated all previous royal ordinances and, while it strictly forbade the carrying to and selling of liquor in the Indian villages, it permitted the sale of brandy to Indians in any of the settlements of the French. The ordinance was registered by the Sovereign Council of New France, October 16, 1679.

Neither the governor nor the bishop was satisfied with the new law. The former disliked the restrictions which still remained to hamper freedom of trade; the latter deplored the lack of bite in those restrictions. The ordinance of 1679 did not solve the liquor

34. PAC, C II A, 4: 308, "mémoire fait par ordre du Roy sur la difficulté de la traitte des boissons aux sauvages dans le Canada à la Nouvelle France, 24 mai, 1678".

35. "Procès verbal de l'assemblée tenue au chateau de Saint Louis de Quebec, le 10 octobre 1678 et jours suivants au sujet des boissons enyvrantes que l'on traite aux Sauvages"; edited by W.B. Munro in "The Brandy Parliament of 1678"' (Canadian Historical Review, June 1921), 179-189.

36. PAC, C II A 5: 112-3. See also Edits, Ordonnances royaux, déclarations et arrếts du conseil d'état du roi concernant le Canada (Québec, 1854), 235-6. 
problem, but it remained on the statute books as the governing law of the brandy trade for rest of the Ancien Regime.

During the years which followed the mails to Paris were filled with mutual recriminations. Neither governor nor bishop would retreat from the stand which he had taken. Frontenac closed his eyes to the activities of the coureurs de bois and connived at quibbles over the interpretation of the King's ordinance. The bootleggers continued to peddle brandy to the Indians; the Indians continued to drink and to commit all kinds of horrible excesses; the missionaries continued to protest against the liquor trade.

The Intendant Duchesneau allied himself with the bishop and accused the governor of disregarding the law, while the governor's friends replied by accusing his antagonists of themselves engaging in illicit trade ${ }^{37}$. Finally, in 1682, Frontenac was recalled, not as a result of the intrigue of the "Canada-mission party", but owing to his cross-grained, cantankerous nature, and his obvious unwellingness to carry out the King's orders regarding the coureurs de bois.

De la Barre and Denonville, Frontenac's successors, both sympathized with the moral attitude of the Church rather than with the immoral stand of the merchants. Both were Catholics before they were mercantilists. Both endeavoured to curtail the brandy trade, and supplemented the royal ordinance of 1679 with regulations of their own. Denonville's despatches are filled with distressing accounts of the demoralization of both the Indians and the youth of French Canada consequent upon the unrestricted liquor trade. To the fatal traffic Denonville attributed the great decline in Indian population. "L'usage que je leur vois faire de l'eau de vie", he wrote in a memorandum dated August 10, 1688 "et ce que j'en ay vu mourir depuis que je suis dans le pays me persuade assurement que les grandes boissons d'eau de vie sont la principale cause de la destruction de tous ces sauvages qui estoient habituez parmi les francois

37. See, for instance, La Salle who wrote in 1678 that the Jesuits "refusent l'absolution à ceux qui ne veulent pas promettre de n'en plus vendre, et s'ils meurent en cet état, ils les privent de la sépulture ecclesiasticque; au contraire, ils se permettent a eux mesmes sans aucune difficulte de ce mesme trafic, quoyque toute sorte de trafic soit interdite a tous les ecclesiastiques par les ordonnances du Roy et par une bulle expresse du Pape" (cited in Parkman, op. cit., note, 325. For a refutation of the charges made by Frontenac and others that the Jesuits engaged illicitly in the fur trade see J. Delanglez, Frontenac and the Jesuits (Chicago, 1939). 
dans la colonie"38. He recommended complete prohibition as the only solution and with this recommendation the Intendant Champigny was in complete accord ${ }^{39}$.

With the return of Frontenac as governor for a second term came a return to the old days of unrestricted free trade. Concerned only with the commercial aspects of the liquor trade Frontenac never ceased to assert that the disorders caused by brandy were grossly exaggerated by the Jesuits for their own ends and to claim for the brandy trade advantages which France could ill afford to lose. In a memorandum dated November 12, 1689 he wrote strongly of the "acharnement passionne" of the clergy whose opposition to the liquor trade was alienating the Indians and driving them into the arms of the English ${ }^{40}$.

\section{- IV -}

Although the brandy trade continued without let or hindrance in Acadia and the St. Lawrence valley it was in the west where Antoine Laumet, alias Lamothe de Cadillac, emerged as the leader of the coureur de bois that some of the worst evils of the trade became apparent. At Michimilimackinac, where Cadillac was commandant, the coureurs de bois and the soldiers of the garrison freely traded with the Indians in complete defiance of the royal regulations. Cadillac argued, rather speciously, that Michilimackinac was a French settlement under the terms of the ordinance of 1679 and that he was not breaking the law by selling liquor to the Indians at that post. Both the King and Pontchartrain instructed Frontenac to apply the strict letter of the ordinance and ordered him to punish the violators; but Frontenac evaded his instructions. In 1693 he issued an order which, while forbidding the sale of brandy in the

38. PAC, C II A, 10: 123-4, "mémoire d'un plus grands maux de la colonie, 10 aodt 1688.

39. Eastman, op. cit., 247.

40. PAC, C 11 A,10 544-4, "observations sur l'état des affaires de Canada au départ des vaisseaux, 18 novembre 1689 ". 
Indian village in accordance with the ordinance of 1679 , expressly authorized its sale in the western posts ${ }^{41}$.

The years Cadillac spent as commandant at Michilimackinac were the heyday of the brandy trade. Cadillac had Frontenac's full support and there was little that the missionaries or the Intendant could do but register their protests. It is true that Frontenac's despatches more than once stressed his desire to do away with drunkenness among the Indians, but his actions were more eloquent exponants of his personal views than were his letters to Paris. Both Frontenac and Cadillac found it too profitable to worry about the souls or the bodies of the Indians when money was to be made and alliances were to be maintained.

Cadillac was, however, hypocritical enough, when soliciting royal support for his new post at Detroit, to describe Michilimackinac as "the scene of all debauchery" and the "retreat for all in rebellion against the orders of the King, and for the libertines who set out from Montreal every day taking an enormous quantity of brandy there by the Grand River which they sell to savages"42. This was probably true enough, but his righteous indignation accords ill with his earlier contention that Michilimackinac was one of the largest French villages in Canada and was therefore entitled to enjoy the same rights as other French settlements, including the right to buy and sell brandy to the Indians ${ }^{43}$.

Both Father Carheil, the Jesuit missionary at Michilimackinac, and the Intendant Champigny protested vigorously against Frontenac's actions. In a series of letters the Jesuits warned the King that if the royal ordinances were not enforced the Indians "périront, ils continueront de commettre d'horribles crimes, ils abandonneront

41. PAC, F 3, 7-1:196-200, ordonnance de M. le C. de Frontenac, 12 septembre, 1693. This ordinance was passed in order to nullify an ordinance which had been issued the previous day by Champigny. See P.A.C., B 17: 184 and Rapport de l'archiviste de la province de Quebec, 1927-28, 88-98.

42. Michigan Historical Society Publications, XXXIII, 145, Cadillac to Pontchartrain, September 25, 1702. Cadillac is here citing Ruette d'Auteuil in support of his request for the closing of Michilimackinac and the development of Detroit.

43. PAC, C 11 A, 14: 13-14, Cadillac a Lagny, 3 aout 1695. Fr. Delanglez says of Cadillac "His single outstanding achievement consists in having reintroduced the brandy trade on a greater scale than at any time before his coming" (Mid-America, October, 1945, 255-6). 
la colonie à qui d'ailleurs ils sont très utiles en paix par la chasse, mais particulièrement en guerre contre nos ennemys queux seuls savent atteindre dans les bois, ils perdront la foy qu'ils ont recue au bapteme et ceux qui ne sont pas encore chrétien seront dans l'impossibilité de se convertir"'4. In 1693 an anonymous memoir on the question of liquor trade painted a picture of the impact of alcoholism upon the Indians so black that even those of the Jesuit Relations looked pale and insipid ${ }^{45}$.

After Frontenac's death in 1698 the new Governor Callières and the Intendant Champigny tightened up the liquor regulations. Orders were issued to the various posts prohibiting officers from receiving "presents from the Indians and giving them liquor" ${ }^{46}$. The ordinance of 1679 was once more put into effect. Nevertheless the political argument in favour of the brandy trade remained strong and Callières warned the authorities in Paris that the Indians were threatening to carry their trade to the English should the prohibitory laws be enforced too rigidly ${ }^{47}$.

The liquor trade was never again carried on in the free and open manner of Frontenac's day, but clandestine traffic in brandy never ceased. From time to time reports were sent to France that the illicit brandy trade with the Indians was still being carried on and in 1708 Cadillac was charged with using brandy as the principal article of Indian trade at Detroit. In 1711 the taverns in Montreal and Three Rivers were limited to selling beer and cider to the Indians on the orders of the Intendant, but this order, like the earlier regulations, was never really effective ${ }^{48}$. In 1713 Montreal was the scene of wild drunken disorders during which several Europeans, including the

\footnotetext{
44. PAC, C 11 A, 12: 2 cited in A.G. Bailey, The Conflict of European and Eastern Algonkian Cultures (Saint John, 1937), 73.

45. Ibid., See also Eastman, op. cit., 274-5.

46. PAC, C 11 A, 19: 37-8, Callières et Champigny au ministre, 5 octobre, 1701. 1702.

47. PAC, C 11 A, 20: 32-3, Callières et Beauharnois au ministre, 3 novembre,

48. PAC, C 11 A, 33: 102, Vaudreuil au ministre, 6 novembre 1712 . See also C 11 A, 42: 4, réponse de $M$. de Vaudreuil et Bégon aux plaintes contre M. de Vaudreuil, 25 octobre 1720 . In 1720 the Intendant Bégon published a list of the tavern keepers of Montreal authorized to sell liquor to the French and of beer tavern proprietors authorized to sell beer to the Indians (C $11 \mathrm{~A}, 42$ : 156-7, rolle des cabaretiers de Montréal).
} 
Sieur Nafréchou, was assaulted upon his own doorstep by three drunken Indians ${ }^{40}$.

The fact is that the great dilemma of the brandy trade remained unsolved throughout the whole of the Ancien Regime. How could the moral arguments of the missionaries be reconciled with the political and economic demands of officialdom? The danger - and it was always a very real one - that the thirsty Indians would go over to the enemies of New France to satisfy their thirst, taking with them their trade and their arms, seemed to make the brandy trade a political as well as a commercial necessity. This argument is brought out time and time again in the despatches of Callières and Vaudreuil; and it was an argument which could not but appeal to the civil authorities, especially when the same civil authorities stood to gain financially. Like Frontenac, Vaudreuil might protect his wish to suppress drunkenness, but like Frontenac his protestations never went to the point of curtailing the liquor traffic. He would not go as far as to free the trade entirely as Frontenac had done, but he was prepared to support the recommendations of the Superior Council in 1716 that brandy "in moderate quantities" should be carried to approved posts and that two or three pots might be given to each Indian coming from the "upper countries" as an inducement to trade ${ }^{50}$. Permission might also be given to the Indians to purchase liquor in Montreal "parce que si on leur refusoit absolument ils iroient chés les Anglois en chercher et y porteroient les pelleteries ${ }^{51}$."

Prohibitory decrees were, after all, worse than useless as long as the coureurs de bois could not be controlled and as long as the soldiers in garrison were paid so little that illicit trade was a standing temptation. Prohibition merely made bootleggers out of both of these and did not restrict the trade. It is probably true that the cheaper English goods were as great an inducement to the Indians to trade their furs with the Anglo-Americans as was the stimulation

49. PAC, C 11 A, 43: 220, "delibérations du conseil sur les abus causés par la traite de l'eau de vie avec les sauvages, 19 décembre 1721."

50. New York Colonial Documents, IX: 883-4, "memoir of Father Lafitau and the Council's order thereupon, June 1, 1718."

51. PAC, C 11 A, 41: 105-6, "déliberation du conseil de la marine, mars, 1720". 
of English rum; but the very fact that rum was available even within the vicinity of French posts like that of Detroit made it impossible to enforce the Canadian liquor regulations. The king's instruction to Vaudreuil to permit the Sieur de Tonty to trade brandy with the Indians at Detroit "avec les mesmes précautions qu'au fort frontenac, c'est à dire en petite quantite" ${ }^{22}$ in order that he might compete successfully with the English traders, was a frank recognition of the mercantile problem even if it was a compromise with the moral issues involved.

In 1721 the Intendant Bégon issued an ordinance renewing the prohibitory regulations against the liquor $\operatorname{trade}^{53}$ and in consequence several traders were convicted of trading with the Indians contrary to law and were punished. But the number of convictions was small and the penalties imposed grew progressively less significant $t^{54}$. The king might express his annoyance at the continued disorders reported at Michilimackinac, but the fact that the brandy was always available for the Indians at the royal post at Tadoussac, where the fur trade was carried on for the profit of the government, robbed the royal displeasure of its rectitude ${ }^{55}$.

In 1730 Pierre Herman, Bishop of Samos and Coadjutor of Quebec, reiterated the stand of the ecclesiastical authorities on the brandy question, forbidding all priest-confessors in the diocese to grant absolution to those who had traded liquor with the Indians and reserving the power of absolution to the bishop himself. The order was strongly resented by the people at large. To them the issue was settled. There could be no return to the days of Laval. The civil population and the civil government accepted the necessity of the brandy trade as a matter of policy, hoping only to limit and control the quantities sold and thereby to prevent the worst $1720 "$.

52. PAC, C 11 A, 41: 82, "déliberation du conseil et mémoire du roi, 4 mars

53. Complement des ordonnances et jugements des gouverneurs et intendants du Canada (Canada 1856), 439.

54. In 1722 Jacques Hery Duplanty was fined 500 livres. In 1723 two traders were fined 100 livres each and in $\mathbf{1 7 3 2}$ three habitants were fined the sum of 100 sols. See Ibid., 190-1, 199-200, 266.

55. Lettre de Charles Aubert de la Chesnaye, 24 octobre 1693, cited in Parkman, op. cit., 326. 
features of the trade. On October 1, 1732 Governor Beauharnois frankly admitted that brandy was being sold "comme a l'ordinaire" to the Indians trading at Montreal, and denied that any unpleasantnesses had resulted therefrom. He assured the Minister that every precaution had been taken at Fort Frontenac, Niagara and other western posts, and complained bitterly of the stand taken by the missionary at Detroit in refusing the sacrament of penance to those who traded in brandy. The Church's obstinacy in recognizing the realities of the situation, he alleged, had been prejudicial to the best interests of the settlement, since the Indians had refused to go on the annual hunt without a supply of liquor ${ }^{56}$. Four years later Beauharnois registered another protest against the bishop's refusal to compromise, claiming that the Indians were going to Oswego and that the Canadian fur trade was continuing to suffer from the ecclesiastical intransigeance ${ }^{57}$.

$$
-\mathrm{V}-
$$

During the years which remained to New France there was little change in the situation. The royal ordinance of 1679 , supplemented by local regulations, remained on the statute books. The reservation of the right of absolution, which had been made by Laval and repeated by his successors, was withdrawn. Neither civil nor ecclesiastical threats, fulminations, orders, or appeals had been able to overcome the stronger pull of profits, and political and economic advantage. To the layman the problem was simple; if the Indian was bound to have his liquor (and of that there was never any question) then let him go to perdition on French brandy rather than on English rum. At least Canada might salvage something out of the Indian trade and the Indian alliances. And the bootlegger was omnipresent whatever penalty Church or State might impose. He always is.

\section{George F. G. Stanley, Professor of History Royal Military College of Canada} 1732.

56. PAC, C 11 A, 57: 30-1, Hocquart et Beauharnois au ministre, 1 octobre 1736.

57. PAC, C 11 A, 65: 35-6, Beauharnois et Hocquart au ministre, 12 octobre 